\title{
Satellite Farming in Global Agriculture: New Tech Revolution for Food Security and Planet Safety for Future Generation
}

\section{MB Dastagiri ${ }^{1 *}$ and Naga Sindhuja PV $^{2}$}

${ }^{1}$ Principal Scientist, ICAR-National Academy of Agricultural Research Management, Rajendranagar, Hyderabad, India

${ }^{2}$ Young Professional, ICAR-National Academy of Agricultural Research Management, Rajendranagar, Hyderabad, India

*Corresponding Author: MB Dastagiri, Principal Scientist, ICAR-National

Academy of Agricultural Research Management, Rajendranagar, Hyderabad, India.
Received: February 20, 2020

Published: March 03, 2020

C All rights are reserved by $\mathbf{M B}$

Dastagiri and Naga Sindhuja PV.

\begin{abstract}
Demographers projects earth population will reach 10 billion in 21st Century. Developing countries worry about feeding growing population. This needs satellite farming to meet food security with limited resources and protect ecosystem. This study analyzes the status, role, feasibility and successful models of satellite farming in global agriculture. The review, synthesis, meta-analysis, Delphi survey, opinion, perspectives and vision tools used. Finally, suggested strategies and policies to keep the planet safe for future generation. The results showed that Japan, China, USA, India and Europe are the major countries to contribute work on satellite farming in agriculture across the globe. Israel and Germany are the only two countries practicing satellite farming successfully in the globe. The applications of satellite farming have been utilized to predict adverse climatic conditions. The study found that satellite farming models have to adopt in developing countries particularly and Africa, Asia, Latin American countries. Developed countries like USA, UK, Europe, Australia are using satellite farming certain extent. The results showed that Japan, USA, Europe, India, France and Germany are mainly involved to monitor greenhouse gases with high precision across the space by using different satellites such as GOSTAT-2, OCO-2, OCO-3, GeoCarb, Copernicus Sentinental-5P, HySIS, MicroCarb and MERLIN. Government should conduct the trainings, conferences and meetings on importance of satellite farming. Government should encourage and attract the farmers towards precision farming by providing support financially. Worldwide network integration and mutual cooperation among the countries should be necessary to apply and spread advance technologies all over the world and in decisions to meet obligations to global climate change treaties.
\end{abstract}

Keywords: Satellites Farming; Global Agriculture; Food Security; Planet Safety; Global Institutions

\section{Introduction}

Demographers forecast that in 21st Century the earth population will reach 10 billion but cultivable land is limited. Many developing countries worry about feeding growing population. One of the new best options is Satellite or precision farming in agriculture to meet food security.

The UN FAO helps governments by developed Agro-Ecological Zoning system based on climate, soil, and topography in land use planning [1]. It estimated that the land suitable for crops only 3.5 percent without limitations. As Science advances and Agriculture more knowledge intensive this is time use more innovative methods to make a difference across the globe to securing crop production and protection of natural resources and ecosystems/climate change.

Basically Satellite Farming is a management concept empowered by inception of GPS and GNSS era. It operates based on principle of observing, computing and responding to inter and intrafield crops variability. Satellite images of farmers' fields in detail with GIS enable more accurate and efficient cultivation practices
[2]. The data provided by Remote sensing satellites helps in monitoring drought, soil, snow cover and crop development. Satellite assess rainfall and help farmers in planning time and irrigation requirement of crops.

Planet, aerospace data analytics company collect information about changing planet and operates by earth imaging satellites. This data will be used by decision makers in business, governments to develop new technologies, deliver business outcomes, power research, and solve global toughest challenges [3]. Satellite Agriculture is a farm management approach in using information technology to make sure crops and soil requirement for optimum health and productivity [4].

Agriculture contribute to climate change: Deforestation contribute in emissions 18 percent; Land use changes contribute to climate change significantly. Deforestation, soil erosion, intensive farming contributes to increased carbon concentrations in the atmosphere [5]. Adoption of precision farming technologies and decision support tools is vital to the agricultural industry due to limited land resources, increased risk of food insecurity and obligations to global 
climate change treaties. Satellites for agriculture can be used to deliver the gains required to meet the societal, economic, political and environmental needs [6]. The space data also useful in prediction of at an early stage drought linked crop failures. This is very useful farmers in poor countries. In future, satellite data trends highly useful in monitoring adaptation [7].

MARS (Monitoring Agricultural Resources) crop monitoring service is a global window for aiding an understanding of global food security. This system is based on static data, such as soil maps, crop parameters, administrative regions, and is updated in near real time by including weather observations, weather forecasts and other remote sensing data to provide end-of-season yield forecasts [8]. The earth observation and meteorological satellite infrastructure plays a key role in climate monitoring. EOS (Earth Observing Satellites) data helps in finding real-time updates on current field, soil and crop conditions, real-time decision support, precision profit mapping, disease and pest identification, immediate alerts to canopy conditional change, harvest forecasting, hyper-localized weather, fleet management and performance tracking, animal tracking and monitoring, enhanced field planning, visualization and augmented reality to enable direct in-field assessment of live operational and historical issues [6].

USDA is using NASA satellite mission which measure the water content of soils to monitor global croplands and make commodity forecasts. USDA's Foreign Agricultural Service website reports on regional droughts, floods and crop forecasts [9]. European Space Agency's (ESA) and Soil Moisture and Ocean Salinity Mission (SMAP) provides soil moisture information will help fill critical gaps [10]. Farming and high-tech may help in rising yields, lower waste and greater environmental sustainability. In future using precision technologies like IoT sensors and AI platforms will help the agriculture industry to overcome the needs of a rising global population and to deal with a changing climate [11].

In future satellites observations will become increasingly important to ensure food security for all. Access to objective information about the real-time status of soil, water, crops, pasture and animals will optimize operational planning and decision making and facilitate significant productivity gains across the farming sector. Many tropical countries farmers facing costly challenges like soil conditions, water availability, weather extremes and climate change and food security of populations. Of late for governments systematic climate monitoring became an essential tool to hedge the risks associated with climate change and unsustainable resources management. Hence the study conducted with the following objectives.

\section{Objectives}

- To study the status, role, feasibility and success of satellite farming in global agriculture

- To study the Global organizations dealing with satellite farming

- To study the applications and benefits of satellite farming in global agriculture

- To suggest strategies and policies to keep planet safe for future generation.

\section{Data and Methodology}

This is an explorative study. The research study analyzed the role and significance of satellite farming in global agriculture. The status and future of satellite farming in global agriculture were analyzed. Data were collected on global institutions dealing with satellite farming, different countries using space research in agriculture, application domains, global satellite models in 6 continents from each 3 countries which transformed global agriculture and benefits, regional and global networking systems and Satellites Working on Pollution and Green House Gases and future missions: The study was conducted based on the secondary data sources. The data were collected from NASA, FAO of the United Nations, OECD, European Space Agency, WMO, Weather Monitoring and Forecasting, International Atomic Energy Agency, UNESCO, cigar, brand South Africa Commission for Agricultural Meteorology, World Bank Reports, CGIAR, UNO, meteoblue, UN Office Outer Space Affairs, USDA Foreign Agricultural Service, U.S. Environmental Protection Agency, World Health Organization and International Institute for Applied Systems Analysis. The review, synthesis, meta-analysis, Delphi survey, opinion, perspectives and vision tools have been used. Finally, planet vision was formulated and suggested strategies and policies to keep the planet safe for future generation.

\section{Results and Discussion}

International institutions working on satellite farming in world

The international institutions working on satellite farming in world has been presented in table 1. FAO of the United Nations, UNESCO, UNOSAT, UNPSA, WMO, CNSA, JAXA, ISRO, NASA, ESA and IAEA are some of the major international institutions working on satellite farming in world.

From the Table 1, it is mainly inferred that the aim of FAO of the United Nations is to achieve food security. FAO is involved in satellite farming to fight against climate change by using the combination of Collect Earth Online with SEPAL. UNESCO collaborate among the nations through education, science, culture and communication for contributing peace and security in the world. UNESCO created awareness by using space related activities which provide support to the activities of world heritage convention [12]. United Nations Operational Satellite Applications Programme helps in providing easily accessible of satellite imagery and geographic information to the community. It focused on critical areas such as human security, humanitarian relief, strategic territorial and development planning and also expertise in working how to reduce disasters [13]. United Nations Programme on Space Applications encouraged the use of space technologies regional and worldwide in the agricultural activities for food security and socio-economic development of nation [14]. The main role of WMO is delivering climatic and accurate weather information for development of the nation [15].

Space based observations of WMO are mainly focused on health, agriculture and food security, water and disaster risk reduction. 


\begin{tabular}{|c|c|c|}
\hline $\begin{array}{l}\text { Name of the } \\
\text { organization }\end{array}$ & $\begin{array}{l}\text { Main objective of } \\
\text { the organization }\end{array}$ & Benefitted in terms of agriculture by organization \\
\hline $\begin{array}{l}\text { FAO of the United } \\
\text { Nations }\end{array}$ & $\begin{array}{l}\text { To achieve food security for all } \\
\text { nations and ensure that people } \\
\text { have regular access to enough } \\
\text { rich quality food to lead active, } \\
\text { healthy lives. }\end{array}$ & $\begin{array}{c}\text { Collect Earth Online combined with FAO's Open Foris } \\
\text { strengthen the comprehensive set of innovative tools for } \\
\text { monitoring, measuring and reporting on Land and forest use. } \\
\text { Combination of Collect Earth Online with SEPAL allowed } \\
\text { countries to fight quickly against climate change. }\end{array}$ \\
\hline $\begin{array}{l}\text { United Nations } \\
\text { Educational, } \\
\text { Scientific and } \\
\text { Cultural Organi- } \\
\text { zation (UNESCO) }\end{array}$ & $\begin{array}{l}\text { To contribute security and } \\
\text { peace in the world by upgrading } \\
\text { collaboration among nations } \\
\text { through education, science, } \\
\text { culture and communication. }\end{array}$ & $\begin{array}{l}\text { Space-related activities are aimed at creating awareness and focused on global } \\
\text { ocean observing system, earth observation and providing support of the activi- } \\
\text { ties of the world heritage convention. } \\
\text { Space technologies utilized for the socio- economic } \\
\text { development and well-being of humanity. }\end{array}$ \\
\hline $\begin{array}{l}\text { United Nations } \\
\text { Operational } \\
\text { Satellite Applica- } \\
\text { tions Programme }\end{array}$ & $\begin{array}{l}\text { To build satellite imagery and } \\
\text { geographic information which } \\
\text { helps in easily accessible to the } \\
\text { humanitarian community and } \\
\text { to expertise in working how to } \\
\text { reduce disasters worldwide and } \\
\text { plan sustainable development }\end{array}$ & $\begin{array}{c}\text { UN Operational Satellite Applications Programme helps to fabricate a differ- } \\
\text { ence in critical areas such as human security, humanitarian relief, strategic } \\
\text { territorial and development } \\
\text { planning. }\end{array}$ \\
\hline $\begin{array}{l}\text { United Nations } \\
\text { Programme on } \\
\text { Space Applica- } \\
\text { tions }\end{array}$ & $\begin{array}{l}\text { To encourage the use of space } \\
\text { technology in figuring out } \\
\text { problems of a regional and } \\
\text { worldwide; To further enhance } \\
\text { the capability of Member States, } \\
\text { especially developing countries, } \\
\text { in the use of space-related tech- } \\
\text { nologies for social, cultural and } \\
\text { economic development. }\end{array}$ & $\begin{array}{l}\text { Space Applications used in an area of agriculture and food security. Includes, } \\
\text { employing space technology in India for sustainable development \&food secu- } \\
\text { rity. Monitoring the impact of climate change on agricultural development and } \\
\text { food security in Kenya. And in Pakistan for food and water security in Pakistan. }\end{array}$ \\
\hline $\begin{array}{l}\text { World Meteoro- } \\
\text { logical Organiza- } \\
\text { tion }\end{array}$ & $\begin{array}{l}\text { To provide world expertise } \\
\text { and leadership in international } \\
\text { cooperation in the delivery and } \\
\text { use of high-quality, weather, } \\
\text { climate, hydrological and related } \\
\text { environmental services for the } \\
\text { development of the well-being } \\
\text { of societies of all nations. }\end{array}$ & $\begin{array}{l}\text { WMO space based observations have played an important role in the four es- } \\
\text { sential areas identified among climate application services, namely, agriculture } \\
\text { and food security, health, water, and disaster risk reduction. }\end{array}$ \\
\hline $\begin{array}{l}\text { National Aero- } \\
\text { nautics and Space } \\
\text { Administration }\end{array}$ & $\begin{array}{l}\text { Scientific discovery and explora- } \\
\text { tion for benefiting United States } \\
\text { and humanity }\end{array}$ & $\begin{array}{l}\text { Self-driving tractors has been introduced. } \\
\text { High-resolution NASA satellite data helps water resource managers develop } \\
\text { tools to plan for and mitigate their impacts. } \\
\text { NASA also helped train algorithms to classify land types using satellite imagery. } \\
\text { Commercial computer learning program, now combined with drone images to } \\
\text { assess the stages, types, of growth, and health of crops in fields. }\end{array}$ \\
\hline $\begin{array}{l}\text { European Space } \\
\text { Agency }\end{array}$ & $\begin{array}{l}\text { To mold the development of } \\
\text { space capability of Europe and } \\
\text { ensure that investment in space } \\
\text { continues to deliver benefits to } \\
\text { the citizens of Europe and the } \\
\text { world. }\end{array}$ & $\begin{array}{l}\text { Satellites namely, Copernicus Sentinel missions and ESA's SMOS of Europe } \\
\text { and the upcoming Florescence Explorer, FLEX, contribute a wealth of informa- } \\
\text { tion about growing conditions and crop health that can be used to improve } \\
\text { efficiency of agriculture. } \\
\text { The Sentinel missions used for revolutionizing the way how to use satellite } \\
\text { data for practical purposes such as farming. }\end{array}$ \\
\hline $\begin{array}{l}\text { Weather } \\
\text { Monitoring and } \\
\text { Forecasting }\end{array}$ & $\begin{array}{l}\text { To forecast climatic parameters } \\
\text { such as temperature, humidity, } \\
\text { soil moisture, and raid detection }\end{array}$ & $\begin{array}{l}\text { Meteorological satellites provide measurements of atmospheric humidity, } \\
\text { temperature and atmospheric winds, concentrations of greenhouse gases and } \\
\text { aerosols, cloud-cover density and cloud particle properties: and allow for near- } \\
\text { continuous monitoring of global weather conditions and forecasting. }\end{array}$ \\
\hline $\begin{array}{l}\text { China National } \\
\text { Space Adminis- } \\
\text { tration }\end{array}$ & $\begin{array}{l}\text { To probe outer space and to fur- } \\
\text { ther enlarge understanding of } \\
\text { the Earth and Cosmos }\end{array}$ & $\begin{array}{l}\text { To monitor floods, typhoons, grassland and forest fires, droughts, sandstorms } \\
\text { and other natural disasters by using Fengyun satellite. } \\
\text { Resource satellite series helps to inquire, manage and monitor the resources of } \\
\text { minerals, land, agriculture, forestry, and water conservancy, as well as geologi- } \\
\text { cal disasters and city planning. } \\
\text { Small satellites used for disaster and environmental forecasting and monitor- } \\
\text { ing have provided critical technical support for surface quality of water and } \\
\text { atmospheric environmental monitoring, major pollution events addressing, } \\
\text { and major natural assessment, disaster monitoring and relief. }\end{array}$ \\
\hline
\end{tabular}




\begin{tabular}{|c|c|c|}
\hline $\begin{array}{l}\text { Indian Space } \\
\text { Research Organi- } \\
\text { zation }\end{array}$ & $\begin{array}{l}\text { To utilize space technology and } \\
\text { its application for various tasks } \\
\text { in nation. }\end{array}$ & $\begin{array}{l}\text { Cartosat-1 and 2, Resourcesat, Risat-1 help in estimation of production and } \\
\text { crop acreage with high precision; assessment of drought and flood damage, } \\
\text { and environmental monitoring. }\end{array}$ \\
\hline $\begin{array}{l}\text { Japan Aerospace } \\
\text { Exploration } \\
\text { Agency }\end{array}$ & $\begin{array}{l}\text { Liable for research, develop- } \\
\text { ment of technology and launch } \\
\text { of satellites into orbit, and is } \\
\text { involved in more advanced } \\
\text { missions such as asteroid } \\
\text { exploration and possible human } \\
\text { exploration of the Moon. }\end{array}$ & $\begin{array}{l}\text { The images captured by satellite used for efficient crop control. } \\
\text { ALOS2 solved environmental problems such as global warming and disasters. } \\
\text { PALSAR-2 can work during day and night time and penetrate rain and clouds. } \\
\text { L-band Synthetic Aperture Radar (SAR), which uses long wavelengths, can } \\
\text { observe the ground through branches and leaves, so it can closely watch the } \\
\text { activity of land. }\end{array}$ \\
\hline $\begin{array}{l}\text { International } \\
\text { Atomic Energy } \\
\text { Agency }\end{array}$ & $\begin{array}{l}\text { To encourage the peaceful use } \\
\text { of nuclear energy, and to inhibit } \\
\text { its use for any military purpose, } \\
\text { including nuclear weapons. }\end{array}$ & $\begin{array}{l}\text { IAEA helps in improving nutrition efficiency, verifying the authenticity of milk } \\
\text { and dairy products, improving plant varieties of wheat, rice, maize, soybean } \\
\text { and vegetables. }\end{array}$ \\
\hline
\end{tabular}

Table 1: International Institutions Working on Satellite Farming in World.

Source: The authors synthesized from the sources: FAO, UNESCO, UNOSAT, UNPSA, WMO, WMF, CNSA, JAXA, ISRO, NASA, ESA and IAEA.

NASA explore the scientific discoveries for the benefit of USA and humanity. NASA technologies are mainly involved in agriculture to deliver an information about crop stages, crop health and water resources mangers [16]. ESA develops the space technologies for the benefit of the Europe citizens and the world. The satellite technology helps in improving the farming efficiency [17]. The main aim of WMF is to forecast the weather parameters by that information, precautions can be taken against climate change. CNSA enlarge the understanding of the earth and cosmos. CNSA satellites monitor floods, typhoons, grassland and forest fires, droughts, sandstorms, the resources of minerals, land, agriculture, forestry, and water conservancy, as well as geological disasters and city planning [18]. ISRO uses the space technologies for the nation and helps in accurate crop acreage and production estimates; assessment of drought and flood damage, and environmental monitoring [19]. JAXA explore research technology and launch satellites into the orbit. JAXA invented satellites which gives information related to crop control, observes the activity of land, and solve the environmental disasters [20]. IAEA encouraged the peaceful use of nuclear energy and helps in improving plant varieties, verifying the milk and dairy products authenticity, thus it enhances the nutrition efficiency [21].

\section{Farming by satellites}

Space technologies are useful to policy makers, agronomists, food industry and farmers to increase production and profit simultaneously. Accurate information and analysis can also help predict a region's agricultural output well in advance and critical in anticipating and mitigating food shortages and famines effects.

\section{Worldwide network measuring stations}

Germany GLAM.DE research venture developed innovative methods to use satellite data to incorporate the German expertise in satellite remote sensing in an international network. Big data and artificial intelligence offer new ways to solve age-old problems, such as how to feed a growing population. RTI is funding research and analysis based on these technologies to promote agricultural resilience and food security in Rwanda [22].

\section{World bank group}

This organization developed proven and innovative practices for climate-smart agriculture to increase productivity, strengthen climate resilience and reduce greenhouse gas emissions [3].

\section{Agrometeorogical services}

The third WMO Long Term Plan (1992 - 2001) earlier objectives were "to be of service to sustainable agricultural production in the framework of sustainable development", Havana in 1995, CAgM talked about "strengthening members' indigenous capabilities to provide relevant meteorological services to agriculture and other related sectors". But the resulting applied agro meteorology seldom reaches the livelihoods of farmers in developing countries [23].

World meteorological organization commission for agricultural meteorology CAgM

WMO Inter Commission Task Team (ICTT) is examining the possibility of establishing Regional Climate Centers (RCCs), to forecast, prediction, data set creation, research, education, etc., in countries where they are not expertise. Regional activities centers include ACMAD, AGRHYMET and the DMCs in Africa, and ASMC, ADPC and APCN in South-East Asia (CAgM Report No. 102). Many SIP producers still provide information via the Internet. There are the RCCs, the RCOFs, various regional initiatives, the work of ASPRU, CLIMAG, RES AGRICOLA, and others [24] Matthew (year) outlined: Internet of Things is about: an intertwined network of objects (sensors, irrigators, pumps) interacting together to provide optimal efficiency and predictability [25].

\section{Copernicus-incubation}

AgriBORA is a German start-up developing a location specific Farm Decision Support System for the smallholder agriculture sector in Africa [26]. Artificial intelligence, data analytics, and drones will reshape the future of farming by making it more intelligent, more efficient and better for the planet [27]. 
NASA Harvest to bring valuable satellite imagery data to smallplot farmers in Mali, where insufficient rainfall in 2017 and 2018 led to failed harvests and spikes in the prices of staple cereals and left up many families without enough food to meet their daily needs. NASA Harvest is working with governments across the globe to help them learn to use the data [28]. University of Maryland's Dr. Catherine Nakalembe, the NASA Harvest East Africa lead, says the imagery and the ground-level farm data allow analysts to see where crops are doing better or worse historically [29].

Bill and Melinda Gates Foundation funded Lutheran World Relief in Mali, is using the satellite imagery to strengthen early warning systems that help families recover from losses to crops and herds and support their capacity to withstand future crises [30].

European GNSS Agency (GSA), the EU agency responsible for European satellite navigation activities, and the European Environmental Agency, who provide sound and independent information on the environment for decision makers and the public.

Alex melnitchouck of bayer crop science

Today 's farmers have a lot of knowledge at their fingertips, helped by the spread of mobile communications. Combine this with the latest seed varieties, detailed weather data and crop analysis tools, and they have a better chance to increase production and cope with climate change [31].

\section{Satellite farming models transformed global agriculture}

The countries which used satellite farming and other successful models in Asia, Africa, America, Europe, Latin America and Australia continents are vide in Table 2 . The study found that the successful models of countries are: USA-Industrial farming, Canada -Value-added production, Mexico -Commercial Agriculture, India -Mixed and Multiple Agriculture, China- Intensive Cropping, IsraelPrecision agriculture, Brazil -incentive system, South Africa- Dual agricultural economy, Australia -Conservation farming, UK -Mechanized Agriculture, Germany-Smart Farming, Russia -Market-oriented system, Sweden- Modern farming and Switzerland- Organic farming. But World most producing countries are China, India, USA and Brazil. It is found that Israel and Germany are the only two countries are practicing satellite farming in the globe. These countries satellite farming models have to adopt in developing countries particularly Africa, Asia and Latin American countries.

Developed countries like USA, UK, Europe and Australia are using satellite farming certain extent [5].

\begin{tabular}{|c|c|c|c|}
\hline Continent & Country & $\begin{array}{l}\text { Successful agriculture } \\
\text { models }\end{array}$ & Strategy \\
\hline \multirow[t]{3}{*}{$\begin{array}{l}\text { North } \\
\text { America }\end{array}$} & USA & Industrial agriculture & $\begin{array}{l}\text { Monoculture in large scale, Chemical and pesticide intensive, Industrial meat } \\
\text { production. }\end{array}$ \\
\hline & Canada & Value-added production & $\begin{array}{c}\text { Consumer and Market driven agriculture responsible more exports and increase } \\
\text { more farm income. Farmers advised to grow more value added products. }\end{array}$ \\
\hline & Mexico & Commercial Agriculture & $\begin{array}{l}\text { Farmers grow more export oriented high commercial economic values. Mostly } \\
\text { exported to the U.S.A. }\end{array}$ \\
\hline \multirow[t]{3}{*}{ Asia } & India & $\begin{array}{l}\text { Mixed and Multiple } \\
\text { Agriculture }\end{array}$ & $\begin{array}{l}\text { Multiple and mixed farming models besides allied activities which provide em- } \\
\text { ployment throughout the year. Integrated Farming Models (IFS Models) }\end{array}$ \\
\hline & China & Intensive Cropping & $\begin{array}{l}\text { High intensive nitrogen fertilizer approach to increase higher yields and protein } \\
\text { and in rice. High cropping intensity and IFS models with organic farming in } \\
\text { some regions. }\end{array}$ \\
\hline & Israel & Precision agriculture & $\begin{array}{l}\text { Satellite farming- using satellite innovative technologies data collection and } \\
\text { analysis for efficient and high productive precision farming. }\end{array}$ \\
\hline $\begin{array}{l}\text { Latin } \\
\text { America }\end{array}$ & Brazil & $\begin{array}{l}\text { The incentive system for } \\
\text { low-carbon agriculture }\end{array}$ & $\begin{array}{l}\begin{array}{l}\text { Integration farming system (crops + livestock + forest); Low interest loan ABC } \\
\text { program for sustainable agriculture, development of commercial forests, bio- } \\
\text { logical nitrogen fixation, }\end{array} \\
\text { By } 2020 \text { Greenhouse gas emissions reduction by } 160 \text { million tonnes of carbon } \\
\text { dioxide equivalent annually. }\end{array}$ \\
\hline Africa & $\begin{array}{l}\text { South } \\
\text { Africa }\end{array}$ & $\begin{array}{l}\text { Dual agricultural } \\
\text { economy }\end{array}$ & $\begin{array}{l}\text { Well-developed commercial farming as well as subsistence farming in rural } \\
\text { areas. During winter rainfall, intensive crop production and in summer rainfall } \\
\text { areas mixed farming. }\end{array}$ \\
\hline Australia & Australia & $\begin{array}{l}\text { Conservation farming, } \\
\text { Ley farming }\end{array}$ & $\begin{array}{l}\text { Intensive diversity in cropping system and crop rotations. Sustainable agricul- } \\
\text { ture production systems and biodiversity, and contribute to the preservation of } \\
\text { the natural resources, water and air, while optimizing yields. }\end{array}$ \\
\hline
\end{tabular}




\begin{tabular}{|c|c|c|c|}
\hline \multirow[t]{5}{*}{ Europe } & UK & Mechanized Agriculture & $\begin{array}{l}\text { UK is highly industrialized country due to that farm labor scarce so, farming } \\
\text { mechanized. It increases production, efficiency and leads to Commercial Agri- } \\
\text { culture. }\end{array}$ \\
\hline & Germany & Smart Farming & $\begin{array}{c}\text { Digital technologies resource-saving farming. This technology helps producers } \\
\text { and consumers together, new technologies farmers adoption, and plant diseases } \\
\text { diagnosis. }\end{array}$ \\
\hline & Russia & Market-oriented system & $\begin{array}{l}\text { In Russia, majority of land was under state ownership till 1980's. Later tran- } \\
\text { sition happed to marketed oriented economy with privatization of land and } \\
\text { farm assets. Then agriculture guided by price signals of demand and supply in } \\
\text { resource allocation, investment and distribution. }\end{array}$ \\
\hline & Sweden & Modern farming & $\begin{array}{l}\text { Fertilization and mechanization made high yields possible. Cold climate reduces } \\
\text { growing season much shorter than elsewhere in Europe. }\end{array}$ \\
\hline & $\begin{array}{l}\text { Switzer- } \\
\text { land }\end{array}$ & Organic farming & $\begin{array}{l}\text { Organic fertilizers replaced chemicals to improve soil fertility which tremen- } \\
\text { dously improve the yield naturally. }\end{array}$ \\
\hline \multirow{4}{*}{$\begin{array}{l}\text { World most } \\
\text { producing } \\
\text { countries }\end{array}$} & China & Intensive Farming & \\
\hline & India & $\begin{array}{l}\text { Mixed and Multiple } \\
\text { Agriculture }\end{array}$ & \\
\hline & USA & Industrial agriculture & \\
\hline & Brazil & $\begin{array}{l}\text { The incentive system for } \\
\text { low-carbon agriculture }\end{array}$ & \\
\hline
\end{tabular}

Table 2: Continent wise Countries Satellite Farming models transformed Global agriculture.

Source: The authors synthesized from the sources: israel21c, cigar [32], brandsouthafrica, Department of Agriculture and Rural Development (Northern Ireland) The Scottish Government, 4 liberty.eu, agriculture in Russia, national encyclopedia, FAO. Dastagiri and Bhavigna (2019).

\section{Environment issues}

- Environmental Pollutants: Environmental Pollutants and reasons for pollution are presented in table 3. The major pollutants are soil, water and air pollutants. The major sources of these pollutants are industrial run off and waste, illegal dumping of solid waste and poor agricultural practices. The study found that the major pollutants are soil, water and air.
- Greenhouse Gases: Greenhouse gases, their sources and percentage are shown in table 4 . The major greenhouse gas emissions are $\mathrm{CO}_{2}$ (76\%) which is due to Fossil fuel and industrial process direct human-induced impacts on forestry, $\mathrm{CH} 4$ (76\%) due to Over agricultural activities, waste management, $\mathrm{N}_{2} \mathrm{O} 6 \%$ due to over agricultural activities, and F-gases (2\%) due to industrial process [33].

\begin{tabular}{|c|c|c|}
\hline Types of pollution & Pollutants & Reasons for pollution \\
\hline Soil Pollutants & $\begin{array}{l}\text { Chemical pesticides and herbicides, organic chemicals. } \\
\text { Chromium (Cr), Cadmium ( } \mathrm{Cd} \text { ), Copper (Cu) and zinc (Zn). } \\
\text { Tars and oils, biologically active compounds, radioactive } \\
\text { materials, asbestos and toxic gases }\end{array}$ & $\begin{array}{c}\text { Improper dumping of household, littering of } \\
\text { industrial waste materials, landfill leakage and } \\
\text { poor agricultural practices. }\end{array}$ \\
\hline Air Pollutants & $\begin{array}{l}\text { Lead }(\mathrm{Mb}) \text {, Nitrogen oxides }\left(\mathrm{NO}^{\mathrm{NO}} \mathrm{O}_{2}\right) \text {, Particulate Matter, } \\
\text { Ozone }\left(\mathrm{O}_{3}\right) \text {, Carbon monoxide }(\mathrm{CO}) \text {, Sulphur dioxide }\left(\mathrm{SO}_{2}\right)\end{array}$ & $\begin{array}{l}\text { Incineration of solid wastes and transportation, } \\
\text { industrial processes that result in generation of } \\
\text { heat and power, burning of fossil fuels. }\end{array}$ \\
\hline Water Pollutants & $\begin{array}{c}\text { Nitrates }\left(\mathrm{NO}^{-3}\right) \text {, Fecal Coliform, Mercury }(\mathrm{Hg}) \text {, bacterial } \\
\text { pollution and phosphorous }(\mathrm{P})\end{array}$ & $\begin{array}{l}\text { Improper dumping of solid waste, industrial } \\
\text { waste and agricultural runoff, improper sewage } \\
\text { treatment plants, }\end{array}$ \\
\hline Noise Pollution & $\begin{array}{c}\text { Sound that is more than } 70 \mathrm{Db} \text { is found to effect the normal } \\
\text { life of most of the living organisms. Such sounds are } \\
\text { considered to cause noise pollutions. }\end{array}$ & $\begin{array}{l}\text { Sounds generated by vehicles, trains, aircraft, } \\
\text { industrial manufacturing, constructions, vehicle } \\
\text { alarms or even loud music. }\end{array}$ \\
\hline
\end{tabular}

Table 3: Environmental Pollutants and Reasons for Pollution.

Source: U.S. Environmental Protection Agency, World Health Organization [34]. 


\begin{tabular}{|c|c|c|}
\hline Gases & Source of greenhouse gases & Percentage \\
\hline $\begin{array}{l}\text { Carbon-di-oxide } \\
\left(\mathrm{CO}_{2}\right)\end{array}$ & Fossil fuel and industrial process, land clearing for agriculture, deforestation, Automobile usage & $76 \%$ \\
\hline Methane $\left(\mathrm{CH}_{4}\right)$ & $\begin{array}{l}\text { Inaccurate waste management ,excessive agricultural activities, biomass burning and } \\
\text { disproportionate energy use. }\end{array}$ & $16 \%$ \\
\hline $\begin{array}{l}\text { Nitrous oxide } \\
\left(\mathrm{N}_{2} \mathrm{O}\right)\end{array}$ & $\begin{array}{l}\text { Excessive agricultural activities, such as more chemical fertilizers, pesticides and insecticides, } \\
\text { combustion of fossil fuels. }\end{array}$ & $6 \%$ \\
\hline $\begin{array}{l}\text { Fluorinated Gases } \\
\text { (F-gases) }\end{array}$ & $\begin{array}{l}\text { Excessive use of consumer products that include in release of hydrofluorocarbons (HFCs), } \\
\text { perfluorocarbons (PFCs), and sulfur hexafluoride }\left(\mathrm{SF}_{6}\right) \text { and refrigeration, Industrial processes }\end{array}$ & $2 \%$ \\
\hline
\end{tabular}

Table 4: Greenhouse gases, Their Sources and Percentage.

Source: EPA United States Environmental Protection Agency.

\section{Satellites working on pollution and green house gases}

Country wise different pollution monitoring satellites across the globe has been presented in the Table 5. Monitoring air quality and greenhouse gas emissions from space by satellite remote sensing technology is a new method that is fast growing [35]. In January 2009, Japan launched the first satellite in the world named GOSAT (Greenhouse Gases Observing Satellite) dedicated to greenhouse monitoring which measures $\mathrm{CO}_{2}$ and $\mathrm{CH}_{4}$ densities from 56,000 locations around the world. The Japan Aerospace Exploration Agency launched GOSAT-2 which generated more precise data than GOSAT. After a failed attempt to launch its first spacecraft dedicated to study atmospheric carbon dioxide (Orbiting Carbon Observatory) back in 2009, NASA was successful in launching OCO2 in 2014. OCO-2 is the second successful $\mathrm{CO}_{2}$ observing satellite after Japan's GOSAT with high-precision (better than $0.3 \%$ ). The American space agency is now working on OCO-3, which will be developed and assembled by using spare materials from OCO-2. The instrument will be hosted on the International Space Station [36].

United Sates is scheduled to launch GeoCarb (Geostationary Carbon Observatory) satellite by early 2020 which tracks global carbon cycle from a geostationary orbit and also making it the first satellite of NASA to measure methane near earth surface. 10 million daily observations of the concentrations of $\mathrm{CO}_{2}, \mathrm{CH}_{4}$, and $\mathrm{CO}$ will be gathered from GeoCarb.

ESA launched Copernicus Sentinel-5P in October 2017, is considered to be the world's most advanced pollution monitoring satellite which tracks $\mathrm{CO}, \mathrm{NO}_{2}$, and $\mathrm{O}_{3}$, along with aerosol. Insights gained from Sentinel-5P data has shown that most of the air pollution globally is anthropogenic, and has impelled policymakers to take adequate actions. Sentinel-5P can clearly show the sources of air pollution at the global level.

In November 2018, ISRO launched HySIS, a hyperspectral imaging observation satellite with a mission span of five years. Its main aim is to check the surface of the Earth in visible, shortwave-infrared and near-infrared regions. The satellite monitors pollution from industrial sources. French space agency CNES plans to launch MicroCarb mission in 2021 to monitor and characterize $\mathrm{CO}_{2}$ surface fluxes.

\begin{tabular}{|c|c|c|c|}
\hline $\begin{array}{c}\text { Organization } \\
\text { Name }\end{array}$ & $\begin{array}{c}\text { Country } \\
\text { Name }\end{array}$ & $\begin{array}{l}\text { Name of } \\
\text { Satellite }\end{array}$ & Functions of Satellite \\
\hline JAXA & Japan & $\begin{array}{l}\text { Greenhouse } \\
\text { Gases Observ- } \\
\text { ing Satellite } \\
\text { (GOSAT) }\end{array}$ & $\begin{array}{l}\text { GOSAT measured } \mathrm{CO}_{2} \\
\text { and } \mathrm{CH} 4 \text { densities } \\
\text { from } 56,000 \text { locations } \\
\text { around the world. }\end{array}$ \\
\hline JAXA & Japan & GOSAT-2 & $\begin{array}{l}\text { To generate data of } \\
\text { Greenhouse gases } \\
\text { with high precision }\end{array}$ \\
\hline NASA & USA & OCO-2 & $\begin{array}{l}\mathrm{CO}_{2} \text { observing satellite } \\
\text { which gives more pre- } \\
\text { cise data than earlier } \\
\text { satellites (GOSAT) }\end{array}$ \\
\hline $\begin{array}{l}\text { American } \\
\text { Space Agency }\end{array}$ & USA & OCO-3 & $\begin{array}{l}\text { It functions same as } \\
\text { OCO-2 which measure } \\
\mathrm{CO}_{2}\end{array}$ \\
\hline NASA & USA & GeoCarb & $\begin{array}{c}\text { It gathers } 10 \text { million } \\
\text { daily observations of } \\
\text { the concentrations of } \\
\mathrm{CO}_{2^{\prime}} \mathrm{CH}_{4^{\prime}} \text { and } \mathrm{CO} .\end{array}$ \\
\hline $\begin{array}{l}\text { European } \\
\text { Space Agency }\end{array}$ & Europe & $\begin{array}{l}\text { Copernicus } \\
\text { Sentinel-5P }\end{array}$ & $\begin{array}{l}\text { It considered as the } \\
\text { most advanced pol- } \\
\text { lution monitoring } \\
\text { satellite in the world } \\
\text { which tracks } \mathrm{CO}, \mathrm{NO}_{2} \text {, } \\
\text { Formaldehyde and } \mathrm{O}_{3} \text {, } \\
\text { along with aerosol }\end{array}$ \\
\hline ISRO & India & HySIS & $\begin{array}{l}\text { It studies the surface } \\
\text { of the earth in visible, } \\
\text { shortwave-infrared } \\
\text { and near-infrared } \\
\text { regions and monitors } \\
\text { pollution from indus- } \\
\text { trial sources }\end{array}$ \\
\hline $\begin{array}{l}\text { French space } \\
\text { agency }\end{array}$ & France & MicroCarb & $\begin{array}{l}\text { To monitor and char- } \\
\text { acterize } \mathrm{CO}_{2} \text { surface } \\
\text { fluxes. }\end{array}$ \\
\hline $\begin{array}{l}\text { French- } \\
\text { German } \\
\text { Climate } \\
\text { Mission }\end{array}$ & $\begin{array}{c}\text { France, } \\
\text { Germany }\end{array}$ & MERLIN & $\begin{array}{l}\text { To carry out observa- } \\
\text { tions of atmospheric } \\
\mathrm{CH}_{4} \text { from space based } \\
\text { on an innovative Lidar } \\
\text { instrument for all lati- } \\
\text { tudes using MERLIN. }\end{array}$ \\
\hline
\end{tabular}

Table 5: Country wise Pollution Monitoring Satellites across the Globe.

Source: Committee on Earth Observation Satellite, MDPI and United Space in Europe. 
$\mathrm{CH}_{4}$ is the second-most important anthropogenic greenhouse gas which is responsible for $25 \%$ of global warming and consists of Global Warming Potential 28 to 36 times greater than $\mathrm{CO}_{2}$ over 100 years. This means that stopping methane leaking to the atmosphere has a very large positive impact.

The scientific objective of French-German Climate Machine MERLIN is to deliver observations of atmospheric $\mathrm{CH}_{4}$ from space for all latitudes based on an innovative Lidar instrument. The MERLIN mission opens the path to reduce $\mathrm{CH}_{4}$ surface uncertainty reduction for the different regions [37].

\section{Concepts of future satellite missions}

Some of the satellites are in planning stage for monitoring all greenhouse gases from space and earth [38]. These include the Feng Yun-3G and GOSAT-3 satellites from China and Japan, respectively. European Commission Copernicus Programme is going to develop $\mathrm{CO}_{2}$ Sentinel constellation which will deploy 3 or 4 broadswath (200-350 km) imaging grating spectrometers $\mathrm{CH}_{4}, \mathrm{CO} 2$, and $\mathrm{NO}_{2}$ from spacecraft. TanSat- 2 is the satellite in the China which began working on a constellations of $\mathrm{CO}, \mathrm{CO}_{2}$ and $\mathrm{CH}_{4}$. Commercial organizations and NGOs has developed other greenhouse gas mission including Bluefield Technologies, GHGSat, and the Environmental Defense Fund. Committee on Earth Observation Satellites deployed the global space-based monitoring capabilities by collecting high spatial resolution images of intense $\mathrm{CH}_{4}$ emission plumes rather than global monitoring [36].

\section{Conclusions}

Agriculture forms the basis of the world's food supply. Earth population will reach to 10 billion in 21st century and developing countries worry about food security. Many costly challenges are there for both farmers and the overall food security of populations. Adoption of precision farming technologies is necessary to meet the societal, economic, political and environmental needs.

The results showed that Food and Agriculture Organization of the United Nations, United Nations Educational, Scientific and Cultural Organization, United Nations Operational Satellite Applications Programme, United Nations Programme on Space Applications, World Meteorological Organization, Weather Monitoring and Forecasting, China National Space Administration, Japan Aerospace Exploration Agency, Indian Space Research Organization, NASA, European Space Agency and International Atomic Energy Agency are major international institutions working on satellite farming in world. It means Japan, China, USA, India and Europe are the major countries to contribute work on satellite farming in agriculture across the Globe. The applications of satellite farming have been utilized in predicting adverse climatic conditions such as snow cover, drought and floods; monitoring soil temperature and soil moisture; assessing the rainfall; planning the cropping pattern, the time of sowing, time and amount of irrigation; recommending correct dose of fertilizer and pesticides. This helps in increasing the quality and productivity of crops and also socio- economic development of farmers which lead to food security. It is found that Israel and
Germany are the only two countries are practicing satellite farming in the globe. Satellite farming models developed by them have to be adopted in developing countries particularly in Africa, Asia, Latin American countries. Developed countries like USA, UK, Europe, Australia are using satellite farming to certain extent. Global warming and climate change have become a big issue now-a-days. Hence, many organizations are working to control the pollution which arise from the greenhouse gases especially $\mathrm{Co}_{2}$ and Methane. The results showed that Japan, USA, Europe, India, France and Germany are mainly involved to predict the pollutants by using different satellites such as GOSTAT-2, OCO-2, OCO-3, GeoCarb, Copernicus Sentinental-5P, HySIS, MicroCarb and MERLIN which helps in monitoring greenhouse gases with high precision across the space. United Nations Programme on Space Applications is using space technologies regional and worldwide in the agricultural activities for food security and socio-economic development of nations. The WMO is delivering climatic and accurate weather information for development of the nations. Globally, space technologies are useful to policy makers, agronomists, food industry and farmers to increase production, food security and profit simultaneously. Satellite farming is a future new tech revolution for global agriculture, environmental pollution control and planet safety.

\section{Suggestions}

Farmers are not ready to implement satellite farming or precision agriculture in their own fields due to lack of knowledge on advance technology. Hence, Government should conduct the trainings, conferences and meetings on importance of precision farming or satellite farming. Government should encourage and attract the farmers towards precision farming or satellite farming by providing financial support. Developing countries especially Africa, Asia and Latin countries should adopt satellite farming models to progress and sustain their lives socio-economically. Only some countries such as Japan, China, USA, India, Germany, France and Russia are working on satellites which monitors the greenhouses gases. Scientists from all countries must involve and compete each other intellectually in inventing satellites which monitor greenhouse gases with high precision to predict a region's agricultural output well in advance and critical in anticipating and mitigating food shortages and famines effects. Exchanging the needy resources of one country with other country can benefit mutually in all sectors. Worldwide Network integration and mutual cooperation is necessary to spread advance technologies across the globe.

\section{Bibliography}

1. Food and Agricultural Organization of the United Nations (1945).

2. Molly Brown E. "Satellite Remote Sensing in Agriculture and Food Security Assessment". Procedia Environmental Sciences 307 (2015).

3. Anonymous. "Climate smart agriculture". World Bank Group (2017).

4. Research gate. 
5. Dastagiri M.B., et al. "Planet Agriculture: Global Commons Natural resources, Climate change, Models and Vision to Feed Hungry Planet". Global Advanced Research Journal of Agricultural Science 8.10 (2019) 286-299.

6. Mark Jarman., et al. "Satellite for Agriculture". Agriculture and Horticulture Development Board (2018).

7. Venkatesh S. "Satellite Technology". Science and Technology (2016).

8. Anita Gibson. "Space Technologies and Climate Change". Organization for Economic Co-operation and Development (2014).

9. USDA Foreign Agricultural Service.

10. Kate Ramsayer. "NASA soil moisture data advances global crop forecasts". National Aeronautics and Space Administration (2018).

11. Ayal Karmi. "How Smarter Technology Will Feed the Planet -A tech revolution in agriculture is improving yields and driving down waste". Scientific American (2019).

12. The United Nations Educational, Scientific and Cultural Organization (1945).

13. United Nations Operational Satellite Applications Programme (2001).

14. United Nations Office for Outer Space Affairs (1958).

15. World Meteorological Organization (1950).

16. National Aeronautics and Space Administration (1958).

17. European Space Agency (1975).

18. United States Environmental Protection Agency (1970).

19. Bureau ET. "ISRO to monitor more crops via satellites". The Times Economics News (2018).

20. Japan Aerospace Exploration Agency (2003).

21. International Atomic Energy Agency (1957).

22. RTI International Editors. "Using Satellite Images and Artificial Intelligence to Improve Agricultural Resilience". RTI International (2019).

23. Stigter CJ. "History of Agrometeorogical Services". World Meterological Oraganization (2011).

24. Harrison M., et al. "Use of Seasonal Forecasts and Climate Prediction in Operational Agriculture Report". World Meteorological Organization 102 (2007).

25. Matthew Pearson. "Future Farming: Climate Change, Satellites and Smart Irrigation”. Fleet Space Technologies (2018).
26. Ayal Karmi. "A tech revolution in agriculture is improving yields and driving down waste". Scientific American (2019).

27. Kizito Odhiambo. "Meet our Winners: Agribora". Copernicus Incubation.

28. John Rivera. "Bringing NASA's satellite imagery data to smallplot farmers in Mali”. AgriLinks (2019).

29. Loura Hall. "NASA is everywhere: Farming Tech with Roots in Space". National Aeronautics and Space Administration Space Tech (2019).

30. Gary Fields. "Photo courtesy of NASA Harvest". Lutheran World Relief (2019).

31. Georgina gustin. "Farmers, Don't Count on Technology to Protect Agriculture from Climate Change". Inside Climate News (2018).

32. Compact Idiosyncratic Gapped Alignment Report.

33. Meteorological service created at the University of Basel (2006).

34. World Health Organization (1948).

35. Aditya Chaturvedi. "Eye from the Sky: Satellites to pinpoint greenhouse emissions and air pollution". Geospatial World (2019).

36. CEOS Team members. "A Constellation Architecture for Monitoring Carbon Dioxide and Methane from Space". Committee on Earth Observation Satellite (2018).

37. Anonymous. "MERLIN: A French-German Space Lidar Mission Dedicated to Atmospheric Methane". Molecular Diversity Preservation International and Multidisciplinary Digital Publishing Institute 9.10 (2017): 1052.

38. FAO news. "NASA and FAO launch next-generation geospatial tool". Institute of Agricultural Science for Southern Vietnam (2018).

\section{Assets from publication with us}

- Prompt Acknowledgement after receiving the article

- Thorough Double blinded peer review

- Rapid Publication

- Issue of Publication Certificate

- High visibility of your Published work

Website: www.actascientific.com/

Submit Article: www.actascientific.com/submission.php

Email us: editor@actascientific.com

Contact us: +919182824667 